\title{
Biochemical Characterization of Pectin Methylesterase from Musa acuminata Referring to Delayed Ripening
}

\author{
Charu Verma $^{1}$, R.K. Singh ${ }^{2}$ and Sanjay Mishra ${ }^{1,3, *}$ \\ ${ }^{I}$ Department of Biotechnology \& Microbiology, Institute of Foreign Trade and Management, IFTM Campus, \\ Delhi Road, Moradabad 244 001, U.P., India; ${ }^{2}$ Department of Electronics, Uttarakhand Technical University, \\ Dehradun, U.K., India; 3 School of Biotechnology, IFTM University, Lodhipur Rajput, Delhi Road (NH-24), \\ Moradabad 244 102, U.P., India \\ *Corresponding Author: Email: sanjaymishra@iftmuniversity.ac.in
}

\begin{abstract}
Several cell-wall degrading enzymes have been studied and their action involved in the softening concomitant with ripening of various fruits. However, studies pertaining to pectin methylesterase (PME) that catalyzes the demethylesterification of cell wall polygalacturonans have been very limited especially in fruit tissue. The present study covers the biochemical characterization of pectin methylesterase from Musa acuminata in context to delayed ripening phenomenon, principally dealing withidentification of a PME gene, namely, PME 1 from Grand Naineveriety of banana. The expression of this gene was well correlated with the ripening. After Ethylene treatment the expression of PME1 gene was peaked on day 3 while in control fruit, the progression of ripening was rather slow. The GA content was observed to augment significantly during the course of ripening of banana fruit. The overall data obtained provide new insights into correlation of the expression of PME1 with increased PME1 with increased PME activity as well as pectin content.
\end{abstract}

\section{Introduction}

Banana belongs to Musa species and is very economic and important crop plant. They are rich source of carbohydrates, so play an important role in the diet. There are 100 million people depends on banana for the source of energy [1]. The genome of banana is commonly triploid having AAA type e.g. Cavendish and parthenocarpic [2]. They are monocots and the ripening of fruit is influenced by ethylene. During the ripening of banana fruit, there are various biochemical changes takes place like in carbohydrate composition, cell wall adhesion, formation of volatile compounds and chlorophyll degradation [3]. In banana the extraction of protein and determination of enzyme activity is more difficult due to the presence of high concentration of phenolic and starch content.

On ripening of fruit there was an increase in the rate of respiration and so they needed the supply of ethylene for complete maturation. In banana ripening, the color and taste of pulp becomes changed. It was more softened and more production of its own ethylene and there wasconversion of starch into sugar due to which the color of peel becomes also changed. So, there were some problems for the exportation of banana. On observations it was revealed that during ripening of fruit, there were some changes in the cell wall [4].In some fruits the textural changes, softening and maturation are due to the presence of Pectin [5]. During ripening of fruits, these are decomposed into sugars and acids [5].

The inter-lamella layer in plant cell is composed of galacturonic acid which formed calcium salts on polymerization and was partially esterified by methanol and referred to as pectic component. The textural properties of fruit as well as physical properties of middle lamella was based on salt bridge formed by crosslinking of adjacent pectin molecules and the polymerization and esterification of polygalacturonides [6]. The great strength of green fruit was due to the protopectin or water insoluble pectic which was partially esterified polygalacturonic acid [7]. On fruit ripening, pectin chain length was decreased and converted to water soluble pectin and the texture becomes soft.The cell wall of higher plants consist of polysaccharides mainly pectin [8]. In middle lamella of cell wall the concentration of pectin was highest and was decreased from primary cell wall and then plasma membrane [9]. Pectin is a linear chain of $\alpha-(1 \rightarrow 4)$-linked D-galacturonic acid which are methyl esterified. Pectic enzymes are related with the softening of fruits alongwith the increase in soluble pectins.The mainly enzymes involved in pectin degradation are Polygalacturonase (PG) and pectin methylesterase (PME) [10]. The function of PME is to remove methyl ester groups and further depolymerization takes place by polygalacturonase (PG) to reduce the rigidity [11]. The extraction and purification of PME from different plants including tomatoes [12], oranges [13,14], apples [15,16], and grapefruits [17]. The increased activity of PME has been shown in banana [18], orange [19], tomato [20] and strawberry [21] and remains constant in banana [22], tomato [23], and mango [24] or to decrease in tomatoes [25], avocado [26] and mango [27].The changes in PME activity during ripening in mango fruit was different, which was depended on the 
varieties. In 'Keitt' mango, the activity of PME was decreased [28], but in some varieties of Pakistani mango it was remains conatant[24], or in African mango the activity was increased [29].

There were thousands varieties of banana in this world for their great value. For our study we chose the Grand naine variety of banana. Grand naine (Dwarf Cavendish) banana also called as 'Mons Mari', 'Williams's hybrid or giant Cavendish due to their high yield (approx. 30Kgs/plant). These were long, cylindrical fruits with less curvature. Grand naine is a cultivar of Cavendish banana with 33 chromosomes and AAA triploid genotype. They produce seedless fruit through parthenocarpy [30]. They reproduce vegetative and lack sexual reproduction. Due to longer shelf life and fast grower plant, Dinar Cavendish is the main export banana. Grand naine variety of banana will ripenfast; its flavor will be richer and contains a firm fleshy fruit. This variety can bear bunches with upto 90 bananas and can withstand in windy and hardly environment. The outer covering of fruit was thick, smooth and yellowish green in color on ripening. It has pleasant aroma, fine textured and sweet in taste. Grand naine variety of banana may soon become the most preferred variety due to its tolerance to abiotic stresses and good quality bunches. Thus, the present study was undertaken to investigate the significance of PME to differential softening and to characterize the PME expression in Grand naine variety of banana during development and ripening at the biochemical level and molecular mRNA translation.

\section{Materials and Methods}

Plant material and sample preparation: Mature unripe Grand naine variety of banana was harvested from the orchard of Biotech. Park, Lucknow, India.Ethylene treatment was given in the concentration of $100 \mu 1$ to initiate the ripening for 24 hours in a closed chamber. The treated banana samples were allowed to ripen for 6 days at room temperature in same conditions without supply of extra ethylene. The sampled were collected at three stages namely unripe, mid-ripen and fully ripened on $1^{\text {st }}, 3^{\text {rd }}$ and $6^{\text {th }}$ day respectively ofboth ethylene treated as well as untreated samples referred to as control samples. The pulp of banana tissue was separated and crushed with liquid nitrogen and then stored at $-80^{\circ} \mathrm{C}$ until the further use.

Fruit Firmness: The firmness of ethylene treated as well as control banana fruits were measured on 0 Day, $1^{\text {st }}$ Day, $3^{\text {rd }}$ Day and $6^{\text {th }}$ Day. The peel of banana fruit was removed and the measurement were recorded byPenetrometer (model FT 327, QA Supplies, Norfolk VA). The measurements were recorded as Newton (N).

Pectin Extraction: The polysaccharides of cell wall were obtained as alcohol insoluble solids (AIS) described by Rosliet al [31] and from AIS, the pectins were recovered as water soluble pectin (WSP), chelator soluble pectin (CSP) and $\mathrm{HCl}$ soluble pectin (HSP) [32]. Twelve gram of powdered sample of banana (both treated and control) was mixed with $50 \mathrm{ml}$ of ethanol followed by boiling for $30 \mathrm{~min}$. The residue obtained after filtration called as AIS, washed twice with absolute ethanol. Fifty to sixty mg of AIS was suspended in $60 \mathrm{ml}$ of distilled water and incubated at $20^{\circ} \mathrm{C}$ overnight with continuous stirring. After filtration, the residue was washed twice with $5 \mathrm{ml}$ of water. The filtrate was called as WSP. The residue was extracted with $50 \mathrm{ml}$ of EDTA $(0.05 \mathrm{M}$ in $0.05 \mathrm{M}$ sodium acetate, $\mathrm{pH}=4.5)$. After filtration the filtrate was designated as CSP. The residue was treated with $0.05 \mathrm{M} \mathrm{HCl}$ at $100^{\circ} \mathrm{C}$ for one hour and the filterate was called as HSP fraction.

Pectin Estimation: All of the extracted fractions, WSP, CSP and HSP were analyzed for their galacturonic acid content by m-hydroxydiphenyl method [33] with some modifications by using D- GA as a standard curve [34]. The samples were taken in triplicates. $400 \mu 1$ of aliquots from each hydrolysate were taken in tubes. $2.4 \mathrm{ml}$ of $75 \mathrm{mM}$ sodium tetraborate in $\mathrm{H}_{2} \mathrm{SO}_{4}$ were added and vortex it. The tubes were placed at $100^{\circ} \mathrm{C}$ in water bath for $15 \mathrm{~min}$, and then cool them into an ice bath for $10 \mathrm{~min}$. $80 \mu 1 \mathrm{of}$-hydroxydiphenyl solution was added to each tube and in control sample solution $80 \mu \mathrm{l}$ of $0.5 \% \mathrm{NaOH}$ was added. All the tubes were vortexed properly for mixing. A pink color was developed within 5 to $10 \mathrm{~min}$. The absorbance was monitored at $525 \mathrm{~nm}$. The amount of pectin was expressed as nmolGAg ${ }^{-1} \mathrm{AIS}$.

Total Enzyme Extraction: The homogenate was prepared by crushing $1 \mathrm{~g}$ of pulp tissue with $3 \mathrm{ml}$ PBS (1X) buffer. The samples were taken in duplicates. The homogenate was centrifuged at $14000 \mathrm{rpm}$ for $30 \mathrm{~min}$ at $4^{0} \mathrm{C}$. The supernatant was taken in fresh tubes and the protein content was measured according to the protocol described by Lowry et al. [35].

PME Assay: The activity of PME enzyme can be analyzed by various methods, but the most common method was Volumetric analysis or titration method. The reaction mixture was composed of $15 \mathrm{ml}$ of $0.25 \%$ citrus pectin solution with $0.15 \mathrm{M} \mathrm{NaCl}$. The protein sample of $200 \mu \mathrm{l}$ was added and the final volume was makeup to $30 \mathrm{ml}$ with distilled water. The $\mathrm{pH}$ of solution was adjusted to 8.0 by $0.01 \mathrm{M} \mathrm{NaOH}$ or $0.01 \mathrm{M} \mathrm{HCl}$. The reaction mixture was incubated at $30^{\circ} \mathrm{C}$ for one hour and then heat for 4-5 min. After cooling, these mixtures were treated with $0.1 \mathrm{M} \mathrm{NaOH}$. Phenophthalein was used as an indicator dye.The activity of PME was also observed 
by Gel diffusion method. In this method $2 \%$ agarose gel was prepared in PBS buffer. $4 \mathrm{~g}$ of agarose was added in $200 \mathrm{ml}$ of PBS buffer and left for 10-15 min at room temperature. The gel was poured in circular disc.

RNA extraction, Reverse transcription and PCR: RNA extraction was carried out from the pulp of all banana samples by using centryltrimethyl ammonium bromide as described by Asifet al. [36]. The resulted RNA of banana pulp was treated with RNase for the synthesis of complementary DNA or c-DNA. Reverse transcription was carried out by using 3' oligodT primer and moloney murine leukemia virus reverse transcriptase (invitrogen, Carlsbad, CA). To amplify the PME gene fragment from banana, primer PME F1 5'CTTTTACCGCAGGGTTGA 3' and 3'AP primers were used.

\section{Results}

Firmness: The ripening of Grand naine variety of banana takes place rapidly on ethylene treatment. The penetration force of fruit was decreased from $12 \mathrm{~N}$ to $2 \mathrm{~N}$ within three days. The control samples without ethylene treated were also showed the decreased penetration force from $12 \mathrm{~N}$ to $10.5 \mathrm{~N}$ due to the decreased in firmness. On $6^{\text {th }}$ Day the ethylene treated samples were ripened fully and the penetration force was on. (Fig.1)

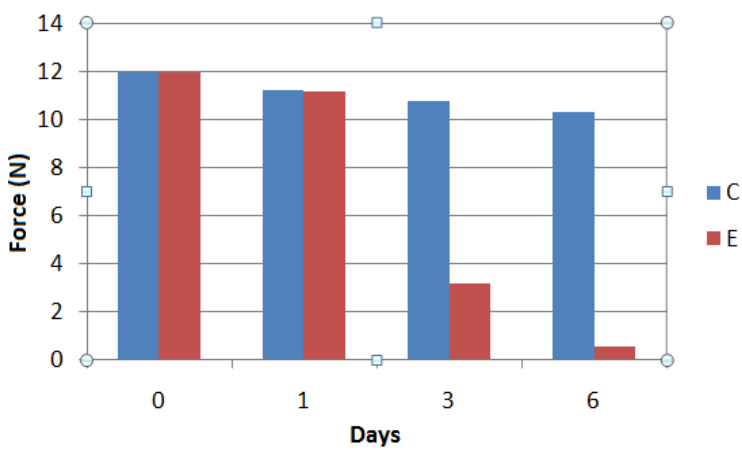

Fig1. Firmness changes during ripening in banana. Firmness was measured in ethylene treated and control (without exogenous ethylene treatment) for 6 Days. 1-6 numbers show days, ' $\mathrm{E}$ ' ethylene treated fruits and ' $\mathrm{C}$ ', control fruit samples.

Pectin degradation during ripening in banana: The degradation of pectin during ripening in banana, the pectinswas estimated as WSP, CSP and HSP of AIS [Table 1]. The total pectin content was decreased during ripening which showed the solubilization of pectins. The uronic acid level was increased in WSP. The GA content was increased significantly during ethylene induced ripening in banana. On $6^{\text {th }}$ Day, the amount of soluble uronide levels was several times more as compared to 0 Day. On the other hand, the amount of CSP and HSP was observerd to be decreased Fig.2). In ethylene treated banana samples, the value of pectin degradation was higher as compared to control or untreated samples.

Table 1.Changes in pectin (nmol GA $\mathrm{g}^{-1}$ AIS) in different fractions of cell wall from control and ethylene treated at day 1, day 3 and day 6 . The values are mean \pm SD of 3 sets of experiments with triplicates in each set.

\begin{tabular}{|c|c|c|c|c|c|c|}
\hline & \multicolumn{2}{|c|}{ Day 1} & \multicolumn{2}{|c|}{ Day 3} & \multicolumn{2}{|c|}{ Day 6} \\
\hline & $\mathrm{C}_{2} \mathrm{H}_{4}$ & Control & $\mathrm{C}_{2} \mathrm{H}_{4}$ & Control & $\mathrm{C}_{2} \mathrm{H}_{4}$ & Control \\
\hline & & & & 29.8 & & \\
\hline \multirow[t]{2}{*}{ WSP } & $17.5( \pm 1.05)$ & $14.1( \pm 1.40)$ & $34.5( \pm 1.49)$ & $( \pm 1.01)$ & $50.5( \pm 1.79)$ & $52.0( \pm 0.90)$ \\
\hline & & & & 65.2 & & \\
\hline \multirow[t]{2}{*}{ CSP } & $75.8( \pm 1.31)$ & $80.1( \pm 1.05)$ & $51.8( \pm 1.51)$ & $( \pm 1.12)$ & $35.1( \pm 1.40)$ & $51.2( \pm 1.91)$ \\
\hline & & & & 55.2 & & \\
\hline HSP & $69.8( \pm 0.55)$ & $60.1( \pm 1.61)$ & $45.8( \pm 1.05)$ & $( \pm 1.21)$ & $34.8( \pm 1.01)$ & $40.1( \pm 1.56)$ \\
\hline Total & & 150.2 & 140.6 & 148.5 & 120.1 & 149.2 \\
\hline Pectin & $165.5( \pm 1.02)$ & $( \pm 3.15)$ & $( \pm 1.59)$ & $( \pm 1.32)$ & $( \pm 1.40)$ & $( \pm 4.28)$ \\
\hline
\end{tabular}

Galacturonic acid is a major component of the pectin polysaccharhamnogalacturonan. On ripening, the concentration of sugar was increased, which reacts with Conc. $\mathrm{H}_{2} \mathrm{SO}_{4}$ to yield product of pink color [Fig. 2]. 


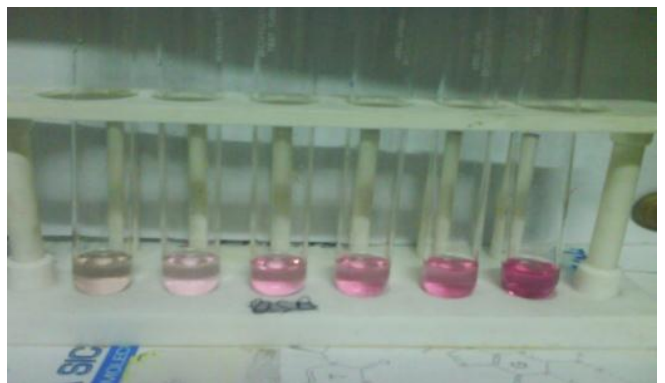

Fig 2.Galacturonic acid is a major component of the pectin polysaccharhamnogalacturonan. Higher the intensity of pink color reflecting higher yield of galacturonic acid during ripening of banana.

PME activity in banana: The activity of PME was measured in the banana pulp during ripening. By the titrametric analysis, the activity of PME was calculated as

$$
\mathrm{PME} \text { units } / \mathrm{ml}=\frac{(\mathrm{ml} \text { of } \mathrm{NaOH})(\text { molarity of } \mathrm{NaOH})(1000)}{(\text { time })(\mathrm{ml} \text { of sample })}
$$

The activity of PME was observed in specific unit i.e. U/mg. The value of PME activity resulted by volumetric analysis is shown in Table 2 and Fig 3.

Table 2. PME activity (U/ml) and relevant specific activity (U/mg protein) in different fractions of cell wall from control (C) and ethylene treated (T) at day 1 , day 3 and day 6 . The values are mean \pm SD of 3 sets of experiments with triplicates in each set.

\begin{tabular}{|l|l|l|l|}
\hline S.no. & Sample & PME activity $(\mathrm{U} / \mathrm{ml})$ & Specific unit \\
\hline 1. & C-0 & $100.00 \pm 4.50$ & $127.71 \pm 3.91$ \\
\hline 2. & C-1 & $73.33 \pm 1.83$ & $77.51 \pm 1.73$ \\
\hline 3. & C-3 & $106.66 \pm 3.63$ & $277.01 \pm 3.81$ \\
\hline 4. & C-6 & $60.01 \pm 1.21$ & $68.88 \pm 1.18$ \\
\hline 5. & T-1 & $40.05 \pm 0.95$ & $163.26 \pm 4.27$ \\
\hline 6. & T-3 & $40.10 \pm 1.01$ & $96.15 \pm 1.85$ \\
\hline 7. & T-6 & $86.66 \pm 2.36$ & $62.07 \pm 1.97$ \\
\hline
\end{tabular}

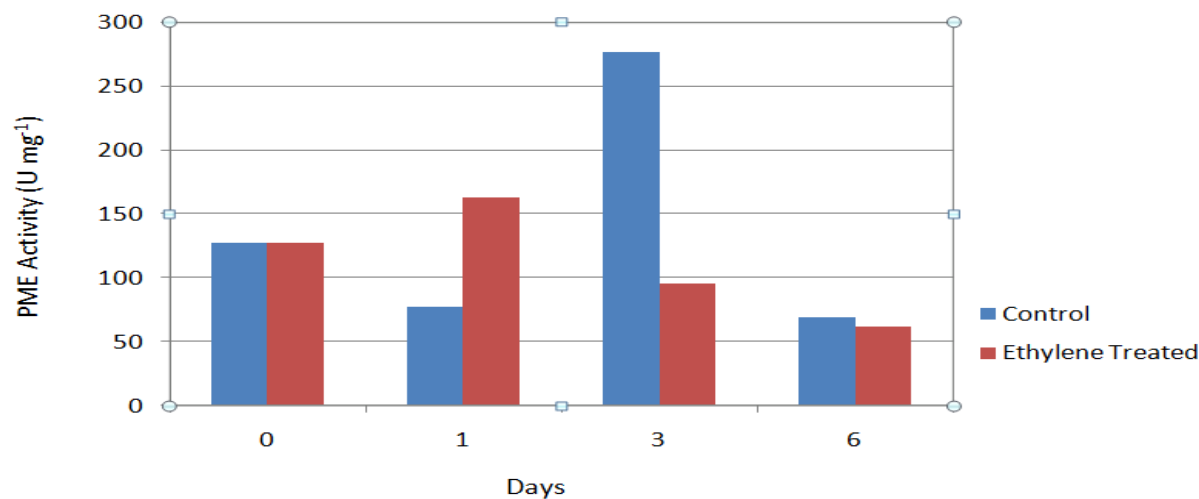

Fig. 3. PME Specific activity $\left(\mathrm{U} \mathrm{mg}^{-1}\right)$ in different fractions of cell wall from control $(C)$ and ethylene treated (T) at day 1, day 3 and day 6 . The graphical data are mean of 3 sets of experiments

On the basis of our results it was observed that the activity of PME during ripening of banana was increased first abruptly and then decreased. The activity of PME in ethylene treated samples washigher as compared to control samples due to artificial high rate of ripening as compared to naturally in control samples. But in both cases, the activity of PME was first increased and then decreased.

Expression exploration of PME in banana: The accumulation of transcript of PME1 was studied in banana during ethylene induced ripening. From different stages of ripening, mRNA was isolated and probed with $24 \mathrm{bp}$ fragment of PME1 gene [Fig. 4]. The transcript becomes increased with ripening and was maximum level on day 3 and then there was a decline in transcript level. Similarly it was also detected the delay in transcript accumulation in untreated ethylene banana samples. These results showed that the expression of PME was increased during ripening of banana first and then declined. 

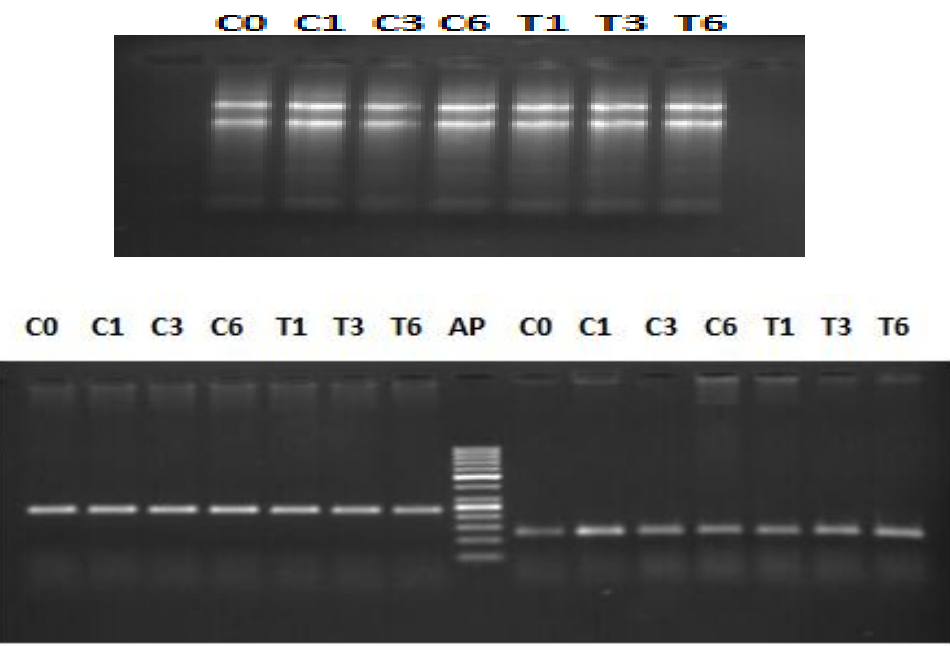

Fig. 4. Reverse Transcription and post- PCR picturization: Expression exploration of PME in banana in different fractions of cell wall from control $(C)$ and ethylene treated $(T)$ at day 1 , day 3 and day 6; AP is the marker.

\section{Discussion}

The objective in this study is to analyze the expression or activity of PME, ripening in Grand Naine variety of Banana fruit. On the ripening of fruit, it becomes softened due to the structural changes in the cell wall by the activity of many hydrolases enzymes [37]. In primary hcell wall, the main component is Pectin \& their degradation is the cause of fruit softening. The main hydrolases enzymes are responsible for pectin degradation PME, PG. PME catalyzes the demethylation of carboxylic group of galacturonosyl residue \& their PG helps in degradation of pectin. It has been studied that during ripening in tomato, the high susceptibility of cell walls to PG action is due to the activity of PME [38].Banana like strawberry undergoes rapid softening due to increase in the content of WSP \& also decrease in insoluble pectin [39,40]. The activity of PME gradually increase on ripening of fruit. More or less in similar fashion, the level of PME protein during tomato ripening has been observed to increase beyond the turning stage while the PME activity begins to decline from its maximum at the time of picking to a low level early in the climacteric fruits [41].

We have identified a PME gene PME 1 from Grand Naineveriety of banana. The expression of this gene was correlated with the ripening. After Ethylene treatment the expression of PME1 gene was peaked on day $3^{\text {rd }}$ while in control fruit, the progression of ripening was slow. On the basis of our study, we can correlate the expression of PME1 with increased PME1 with increased PME activity as well as pectin content. The GA content was observed to augment significantly during the course of ripening of banana fruit. The activity of pectin degrading and softening related PME is abruptly increased in ethylene induced ripening and slowly in control and after sometime its activity becomes decline in Grand Naine variety of banana. This study also challenges the accepted views of the mechanism and function of pectin methylesterases, including the cosecretion of pectins and pectin methylesterases into the apoplasm, new action patterns of mature pectin methylesterases and a possible function of the pro regions of pectin methylesterases as intramolecular chaperones [42]. In conclusion, taken together the data very recently obtained by Verma et al. [43], the present study provides new insights into establishing certain putative biochemical markers (cell-wall degrading enzymeactivators/inhibitors) probably attributing to fruit softening/ripening.

\section{Acknowledgement}

The present study is a part of Ph.D. program of author (CV) who is registered at Uttarakhand Technical University, Dehradun, U.K., India. Authors are also grateful to Dr. Uma Shanker, Consultant Scientist, Biotech Park, Lucknow, U.P., India for his generous laboratory support and throughout inspiration for accomplishment of this study.

\section{References}

[1] P.Rowe, 1981, Breeding an 'intractable' crop: banana. In KO Rachie, JM Lyman, eds, Genetic Engineering for Crop Improvement, A Rockefeller Conference, 12-15 May 1980, The Rockefeller Foundation, New York, NY.

[2] N.W.Simmondsand R.H. Stover 1987, Bananas. Longman, London.

[3] G.B.Seymour, Banana In G.B.Seymour, J.E.Taylor and G.A.Tucker, eds, Biochemistry of Fruit Ripening, Chapman and Hall, London, 1993, 83-106.

[4] N.J.S.Smith, Texture and Biochemical Changes during Ripening of Bananas. Ph.D. Thesis, University of Notthingham, UK, 1989. 
[5] W.Pilinik and A.G.J. Voracen, Pectic substances and enzymes during ripening and storage of Keitt mangoes, In The Biochemistry of Fruits and Their Products, ed. AC. Hulme, 1(53), 1970 London: Academic Press.

[6] M.C.Bourne, Physical properties and structure of horticultural crops, In: Peleg M, Bagley EB, editors. Physical properties of foods. Connecticut: AVI Publishing Company, Inc. 1983, 207-228.

[7] M.A. Joslyn, The chemistry of protopectin: A critical review of historical data and recent developments, Adv Food Res, 11(1), 1962,11 (1): 107.

[8] A.G.J.Voragen, W. Pilnik, J.F.Thibault, M.A.V. Axelos and C.M.G.C. Renard, Pectins. In: Stephen AM, editor. Food polysaccharides and their applications. New York: Marcel Dekker, 1995, 287-339.

[9] B.R.Thakur, A.K. Handa,Chemistry and uses of pectin, Crit Rev Food SciNutr, 1997, 37: 47-73.

[10] S.J.Kays, Postharvest Physiology of Perishable Plant Product, Georgia: Exon Press, 1997, 532.

[11] J. Alonso, N. Howell and W. Canet, Purification and characterisation of two pectinmethylesterase from persimmon (Diospyros kaki), JSci Food Agric, 1997, 75: 352-358.

[12] A.Giovane,L. Quagliuolo,L. Servillo,C. Balestrieri,B.Laratta,R. Loiudice and D.Castaldo, Purification andcharacterization of three isozymes of pectin methylesterase from tomato fruit. J Food Biochem, 1994, 17: 339-349.

[13] C.Versteeg, F.M. Rombouts and W.Pilnik, Purification and some characteristics of two pectinesteraseisoenzymes from orange, LebensmWiss u Technol ,1978, 11: 267-274.

[14] W.N.Hou, Y. Jeong, B.L. Walker,C.L. Wei and M.R.Marshall, Isolation and characterization of pectinesterase from Valencia orange, J Food Biochem, 1997, 21: 309-333.

[15] H.M.Macdonald, R.Evans, Purification and properties of apple pectinesterase, J Sci Food Agric, 1996, 70: 321 - 326.

[16] J.M.Denes,A. Baron and J.F. Drilleau,Purification, properties and heat inactivation of pectin methylesterase from apple (cv Golden Delicious), J Sci Food Agric, 2000, 80: 1503-1509.

[17] T.A.Seymour, J.F.Preston, L.Wicker, J.Lindsay and M.R.Marshall, Purification and properties of pectinesterase of Marsh White grapefruit pulp, J Agric Food Chem, 1991,39: 1080-1085.

[18] H.O.Hultin and A.S.Levine, Pectin methyl esterase in the ripening banana, J Food Sci, 1965, 30: 917-921.

[19] M.A.Tahir, M.S. Chaudhary and A.A. Malik, Pectinesterase (PE) activity in component parts of Jaffa oranges during ripening, Pak J Sci Res, 1975, 27: 59-60.

[20] G.E.Hobson, Pectinesterase in normal and abnormal tomato plants, Biochem J, 1963, 86: 358-365.

[21] M.F.Barnes and B.J.Patchett, Cell wall degrading enzymes and the softening of senescent strawberry fruit, J Food Sci , 1976, 41: $1392-1395$.

[22] C.J.Brady, The pectinesterase of the pulp of banana fruit, Aust J Plant Physiol ,1976, 3: 163-172.

[23] M. Sawamura. E. Knegt and J. Bruinsm, Levels of endogenous ethylene, carbon dioxide, and soluble pectin, and activities of pectin methylesterase and polygalacturonase in ripening tomato fruits, Plant Cell Physiol, 1978, 19: 1061-1069.

[24] M. Ashraf, N. Khan, M. Ahmad and M. Elahi, Studies on the pectinesterase activity and some chemical constituents of some Pakistani mango varieties during storage ripening, J Agric Food Chem, 1981, 29: 526-528.

[25] R.Pressey, J.K. Avants,Multiple forms of pectin methylesterase in tomatoes, Phytochem, 1972, 11: 3139-3142.

[26] A.H.Rouse and C.R. Barmore, Changes in pectic substances during ripening of avocadoes, HortSci, $1974,9: 36-37$.

[27] B.Roe and J.H.Bruemmer, Changes in pectic substances and enzyme during ripening and storage of keitt mango, J. Food Sci., 1981, 54: 186-189.

[28] B.Roe andJ.Bruemmer, Changes in pectic substances and enzymes during ripening and storage of 'Keitt'mango, J Food Sci, 46, 1981, 186-189.

[29] J.O.Aina and O.O.Oladunjoye, Respiration, pectolytic activity and textural changes in ripening African mango (Irvingiagabonensis) fruits, J Sci Food Agric, 1993, 63: 451-454.

[30] Randy, Banana and plantain-an overview with emphasis on Pacific island cultivars, Species Profiles for Pacific Island Agroforestry, 2007.

[31] H.G.Rosli, P.M.Civello and G.A.Martinez, Changes in cell wall composition of three Fragariaxananassa cultivars with different softening rate during ripening, PlantphysiolBiochem, 2004, 42: 823-831.

[32] A.Chourasia, V.A.Sane and P.Nath, Differential expression of pectatelyase during ethylene induced postharvest softening of mango. PhysiologiaPlantarum, 2006, 128: 546-555.

[33] N.Bluemenkrantzand G.A.Hansen, New method for quantitative determination of uronic acids, Anal Biochem, 1973, 54: 484-489.

[34] D.M.Laurence and B.G.Smith, Determination of the uronic acid content of plant cell walls using a colorimetric assays, Food anal chem., 2001.

[35] O.H. Lowry, N.J. Rosebrough, A.L. Farr, and R.J. Randall, Protein measurement with the Folin Phenol reagent. J. Biol. Chem.1951, 193: 265-275.

[36] M.H.Asif, P. Dhawan, and P. Nath, A simple procedure for the isolation of high quality RNA from ripening banana fruit. Plant Mol. Biol. Rptr. 2000, 18:109-115.

[37] Hubert et al., The role of the cell wall hydrolases in fruit softening, Hortic. Ver, 1983, 5: 169-219.

[38] J.L.Koch et al., Tomato fruit cell wall I. Use of purified tomato polygalacturonase and pectinesterase to identify developmental changes in pectin, Plant physiology , 1989, 91 (91): 816-822.

[39] H.M.Yashoda, T.N.Prabha and R.N.Tharanathan, Mango ripening- chemical and structural characterization of pectic and hemicellulosic polysaccharides, CarbohydrRes , 2005, 340: 1335-1342.

[40] H.M.Yashoda, T.N.Prabha and R.N.Tharanathan,Mango ripening: changes in cell wall constituents in relationto textural softening, J. Food Agric , 2006, 86: 713-721.

[41] M.Awad and R.E.Young, Postharvest variation in cellulase, polygalacturonase and pectin methylesterase in avocado (Perseaamericana) fruit in relation to respiration and ethylene production, Plant Physiol., 1979, 64: 306-308.

[42] F. Micheli, Pectin methylesterases: cell wall enzymes with important roles in plant physiology. Trends Plant Sci. 2001, 6 (9): 414419.

[43] C. Verma, S. Gupta, R.K. Singh and S. Mishra, Insilicostudy of pectin methylesterase in Musa acuminate for delayed ripening. 2013, 1(5): 175-182. 